Postgrad. MED. J., (1966), 42, 83

\title{
RUBELLA SYNDROME
}

\author{
A Melvin Ramsay, M.A., M.D., \\ Consultant Physician in Infectious Diseases, Royal Free Hospital. \\ Consultant in Infectious Diseases, North West Metropolitan Hospital Board. \\ Lecturer in Infectious Diseases, University of London. \\ Consultant in Smallpox to the Ministry of Health.
}

Almost a quarter of a century has elapsed since Gregg (1941) first drew attention to the connection between rubella in early pregnancy and the occurrence of developmental defects in the foetus. While the original studies by Swan, Tostevin, Moore, Mayo and Black (1943) based on retrospective evidence suggested that damage to the foetus occurred in about $80 \%$ of cases, recent work based on sound prospective studies has shown that the true figure is somewhere between 10 and $25 \%$. Two extensive prospective surveys by Lundström (1962) in Sweden, and Manson, Logan and Loy (1960) in England showed the incidence of defects following rubella in the first trimester to be $10 \%$ and $15.6 \%$ respectively. The figures might be higher if damage resulting in stillbirths and abortions or minor defects were taken into account. The suggestion by Bell (1959) that all pregnancies in which rubella occurred in the first trimester should be terminated ignores the possibility of a favourable outcome and was severely criticised (Floyd, 1959: Pitt 1959). The sheer impossibility of forecasting the outcome of a pregnancy in which exposure to rubella has occurred is obvious and it is therefore with considerable relief that clinicians have received the advent of laboratory aids to diagnosis, which, although in themselves not sufficient on which to make a decision regarding the termination of pregnancies, can nevertheless throw light on the problem. These include:-

\section{Isolation of the Causative Agent}

Rubella virus has now been isolated in various types of cell culture media, the chief of which are:-

1. Primary human amnion. Weller and Neva (1962) first isolated the virus on primary human amnion cultures (PHA).

2. Monkey kidney cultures. Parkman, Buescher and Artenstein (1962) isolated several agents from the nasopharynx of patients with clinical rubella by inoculation of primary African green monkey (vervet) kidney cultures (GAMK). No cytopathic changes were observed but the inoculated cultures were shown to be resistant to challenge inoculation with a cytopathogenic virus, ECHO 11. These agents were identified as rubella virus in neutralisation tests with rubella antisera.

3. Rabbit kidney cells-RK 13 transformed cells. McCarthy, Taylor-Robinson and Pillinger (1963) reported that rubella virus had been isolated from throat washings, blood and an excised lymph node by inoculation of a continuous line of transformed rabbit kidney cultures-the RK 13 line.
For isolation, vervet monkey kidney cultures are probably the most sensitive; rabbit kidney and human amnion cultures are not quite so sensitive. However, growth on human amnion and rabbit kidney is detectable by cytopathic effect (CPE) whereas growth on vervet monkey kidney must be demonstrated by challenge inoculation with another virus such as ECHO virus type 11 .

With these methods rubella virus has been isolated from the nasopharynx 8 days, and from the blood 6 or 7 days, before the appearance of the rash. Virus has been isolated from the nasopharynx up to 15 days and from the blood 1 or 2 days after the eruption.

\section{Serological Tests}

The following serological tests may be invoked in confirmation of a recent attack of the disease :-

1. Neutralisation tests. Rubella neutralising antibody can be measured by means of the interference-inhibition phenomenon in AGMK cultures, and in primary human amnion (PHA), and in RK 13 cells by means of the cytopathic-inhibition test.

2. Complement fixation test. Sever, Brody, Schiff, McAlister and Cutting (1965) have described a CFT test for rubella. This antibody was demonstrated in patients soon after the disappearance of the rash and persisted for at least 8 months. It could not be demonstrated in patients who had had the disease 10 years previously although neutralising antibody was still detectable.

3. Fluorescent antibody technique. Rubella antibody has been demonstrated by fluorescent antigen-antibody technique.

The advent of reliable laboratory methods of diagnosis has resulted in an accumulation of important new knowledge regarding the pathogenesis, pathology and clinical manifestations of congenital rubella.

Pathogenesis of Congenital Rubella. Foetal infection from rubella virus results primarily from maternal viraemia and there is now firm evidence to show that virus invasion of the foetus is associated with infection of the placenta. Weller, Alford and Neva (1964) isolated virus regularly from both placenta and foetus when maternal rubella has occurred in the first 8 weeks of pregnancy and from 7 placentas but only one foetus during the second 8 weeks of pregnancy. It has been found that infants with rubella defects excrete virus during the post-natal period and virus has been recovered from the nasopharynx and urine for periods ranging from birth to 18 weeks 
(Alford, Neva and Weller, 1964). Corroborative evidence comes from a report that nurses and doctors developed clinical rubella from contact with infants with rubella syndrome defects (Krugman, 1965).

Serological studies on a number of infants with rubella defects revealed high levels of neutralising antibody (Plotkin, Dudgeon and Ramsay, 1963). It has been further shown that this is not passive transfer of maternal antibody (Dudgeon, Butler and Plotkin, 1964). Evidence that the foetus can produce antibody is shown by the high levels of immune macroglobulins found in rubella syndrome infants during the first few weeks of life. The essential difference between the response of the foetus and the adult to rubella is not so much one of antibody production bult an incapacity on the part of the foetus to terminate the infection. Virus excretion continues for several months in the presence of antibody, a situation analogous to that which occurs in cytomegalic inclusion disease.

Pathology of Congenital Rubella. Cell degeneration with minimal necrosis is the basic lesion; there is a virtual absence of inflammatory reaction. Cytoplasmic and occasionally intranuclear inclusions can be found in infected cells. In the eye the main changes are in the lens but it is important to note that in the retina there is interference with the normal development of pigment epithelium. In the ear lesions are confined to the cochlea and the organ of Corti. Information is limited as regards the heart. In the placenta cytoplasmic inclusions have been shown in decidual cells; no necrosis is seen and only a minimal inflammatory reaction with lymphocytes. No changes were noted in the chorionic villi and endometrial glands.

\section{Clinical Manifestations of Congenital Rubella}

1. Eye Defects. Cataract is the most frequent; it is often noticeable at birth as dense opacities in the pupillary area. Bilateral cataract is common. When unilateral, retinal changes may be found in the opposite eye. Embryopathic pigmentary retinopathy accounts for the small bluish pigmented spots, so-called "pepper and salt" changes which are not specific for rubella but occur more commonly following rubella than any other infection. Microphthalmia is often found in cases of rubella cataract but may not be noticed for several months after birth. Choroidoretinitis is sometimes found and glaucoma has recently been described.

2. Congenital heart disease. This is usually of the acyanotic type. Patent ductus arteriosus is the commonest lesion but pulmonary stenosis, atrial and ventricular septal defects and Fallot's tetralogy have been reported.

3. Deafness. This is now known to be the commonest of all abnormalities following maternal rubella. It may not be detected for some years and follow-up examinations of children aged 3 to 8 have shown a much higher incidence than was formerly supposed. The overall incidence of perceptive deafness following rubella in the first 16 weeks of pregnancy is between $19 \%$ (Sheridan, 1964) and 22\% (Barr and Lundström, 1961).

4. Multiple Defects. A recent survey shows a high incidence of mutiple defects involving eyes, ears and heart in varying combinations (Dudgeon, 1965). The most frequent combinations were cataract and heart disease, deafness and heart disease and all three with or without microcephaly.

5. Recently described manifestations of the Rubella Syndrome. Plotkin, Oski, Harnett, Hervada, Friedman and Gowing (1965) and Rudolph, Yow, Phillips, Desmond, Blattner and Melnick (1965) have reported series of infants which, in addition to cataracts and congenital heart disease, had a high incidence of thrombocytopenia, hepato-splenomegaly and osteochondritis with low birth weights. It seems reasonable to suppose that these represent a new manifestation of the effect of rubella virus on the foetus and may possibly be related to an altered virulence of the virus during the 1963-64 U.S.A. pandemic.

\section{Immunity}

Immunity after rubella is long lasting. Although second attacks do occur they are not as frequent as second attacks of measles. Past histories of rubella are frequently unreliable. The most striking evidence of the solid immunity following rubella comes from the recent epidemic in the Pribilofs (Brody, Sever, McAlister, Schiff and Cutting, 1965) in which the adult population of 22 years and over, exposed in the previous epidemic of 1940, were unaffected in 1963. Immunity appears to be related to the presence of neutralising antibody. Approximately $17.5 \%$ of women of child-bearing age are deficient in antibody and therefore theoretically at risk during pregnancy.

\section{Prophylaxis}

The results of prophylaxis with gamma globulin are disappointing in comparison with those obtained in measles. It has been shown on several occasions that normal gamma globulin exerts a protective effect against rubella in children (Graysiton and Watten, 1959) and in a trial of gamma globulin in a London hospital the attack rate was found to be five times lower in the inoculated group who were given $250 \mathrm{mg}$. (McDonald, 1963). The prophylactic value of gamma globulin in pregnancy is more difficult to assess on account of the difficulty in getting controls. Lundström (1961) showed that the attack rate in pregnant women exposed to epidemic rubella was $2.4 \%$ following $4 \mathrm{ml}$. of rubella globulins and nil following $24 \mathrm{ml}$. of normal gamma globulin. Pending the advent of active immunisa- 
tion by either killed or live vaccine, the use of gamma globulin in pregnant women exposed to rubella in the first 16 weeks of pregnancy is still to be recommended. In view of the slightly better protection afforded by $1,500 \mathrm{mg}$. this should be regarded as the minimum dose to be employed.

\section{REFERENCES}

Alford, C. A., JR., Neva, F. A., and Weller, T. H. (1964): Virologic and Serologic Studies on Human Products of Conception after Maternal Rubella New Engl. J. Med., 271, 1275.

BARR, B., and LUNDSTROM, R. (1961): Deafness following Maternal Rubella, Acta oto-laryng. (Stockh.), 53, 413.

BeLL, J. (1959): Rubella in Pregnancy, Brit. med. J., i, 686.

Brody, J. A., Sever, J. L., McAlister, R., Schiff, G. M., and CuTtING, R. (1965): Rubella Epidemic in the Pribilofs; Epidemiologic, Clinical and Serological Findings, J. Amer. med. Ass., 191, 619.

DuDGEON, J. A. (1965): Serological Studies on the Rubella Syndrome, Arch. ges. Virusforsch, 16, 501.

Dudgeon, J. A., Butler, N. R., and Plotkin, S. A. (1964): Further Serological Studies on the Rubella Syndrome, Brit. med. J., ii, 155.

FLoYD, H. (1959): Rubella in Pregnancy, Brit. med. J., i, 1040.

Grayston, J. T., and WATtEN, R. H. (1959): Gamma Globulin in Prevention of Rubella, New Engl. J. Med., 261, 1145 .

GREGG, N. M. (1941): Congenital Cataract following German Measles in the Mother, Trans. opthal. Soc. Aust., 3, 35.

Krugman, S. (1965): The Clinical Use of Gamma Globulin, New Engl. J. Med., 269, 195.

LUNDSTROM, R. (1962): Rubelia during Pregnancy. A Follow-up Study, Acta paediat. (Uppsala), 51, Suppl. 133.

Manson, M. M., Logan, W. P. D., and Loy, R. M. (1960): Rubella and Other Virus Infections during
Pregnancy. Reports on Public Health and Med. Suspects No. 101. London: H.M.S.O.

MoCarthy, K., TAylor-Robinson, C. H., and PilLINGER, S. E. (1963): Isolation of Rubella Virus from Cases in Britain, Lancet, ii, 593.

MCDonald, J. C. (1963: Gamma-Globulin for Prevention of Rubella in Pregnancy, Brit. med. J., ii, 416.

Parkman, P. D., Buescher, E. L., and Artenstein, M. S. (1962): Recovery of Rubella Virus from Army Recruits, Proc. Soc. exp. Biol. (N.Y.), 111, 225.

PiTT, D. B. (1959): Rubella in Pregnancy, Brit. med. J., i, 1301.

Plotkin, S. A., Dudgeon, J. A., and Ramsay, A. M. (1963): Laboratory Studies on Rubella and the Rubella Syndrome, Brit. med. J., ii, 1294.

Plotkin, S. A., Oski, F. A., Hartnett, E. M., HerVADA, A. R., Friedman, S., and Gowing, J. (1965): (No title yet available), J. Pediat., 67, 182.

Rudolph, A. J., Yow, M. D., Phillips, C. A., DesMOND, M. M., BlatTNER, R. J., and MelNiCK, J. L. (1965): Transplacental Rubella in Infants, J. Amer. med. Ass., 193, 843.

Sever, J. L., Brody, J. A., Schiff, G. M., McAlister, R., and CuTting, R. (1965): Rubella Epidemic in the Pribilofs; Clinical and Laboratory Findings, J. Amer. med. Ass., 191, 624.

Sheridan, M. D. (1964): Final Reports of a Prospective Study of Children Whose Mothers had Rubella in Early Pregnancy, Brit. med. J., ii, 536.

Swan, C., Tostevin, A. L., MOORE, B., Mayo, H., and BLACK, G. H. B. (1943): Congenital Defects in Infants Following Infectious Diseases during Pregnancy, Med. J. Aust., 2, 201.

Weller, T. H., and Neva, F. H. (1962): Propagationo in Tissue Culture of Cytopathic Agents from $\mathrm{Pa}-?$ tients with Rubella-like Illness, Proc. Soc. exp. Biol. (N.Y.), iii, 215.

Weller, T. H., Alford, C. A., and Neva, F. A. (1964): Retrospective Diagnosis by Serologic Means of Congenitally Acquired Rubella Infection, New Engl. J. Med., 270, 1039. 